\title{
PENGARUH STRATEGI PROMOSI TERHADAP LOYALITAS SISWA/I PADA SMP MUHAMMADIYAH 4 MARGAHAYU KAB.BANDUNG
}

\author{
Budi Sadarman \\ Indra Sasangka \\ STIE Muhammadiyah Bandung \\ Jl. Karapitan No.143 Bandung
}

\begin{abstract}
Abstrak
Strategi promosi merupakan upaya menarik sebanyak mungkin orang agar mau menggunakan jasa atau barang yang dijual oleh suatu lembaga maupun perusahaan. Dalam hal ini dapat diibaratkan bahwa sekolah merupakan sebuah lembaga yang menjual jasa pendidikan yang bertujuan memperoleh siswa untuk tertarik dan loyal bersekolah di sekolah yang dimaksud.

Metode penelitian yang digunakan adalah metode deskriptif. yang meneliti status kelompok manusia, suatu objek, suatu setting kondisi, suatu system pemikiran, ataupun suatu kelas peristiwa pada masa sekarang. Studi kasus merupakan penelitian yang terperinci mengenai suatu obyek tertentu selama kurun waktu tertentu, termasuk lingkungan dan kondisi masa lalunya dengan cukup mendalam dan menyeluruh. Tujuan dari penelitian deskripsi ini yang mengambil penelitian dengan metode studi kasus adalah membuat deskripsi, gambaran, yang terjadi saat sekarang, masa lalu maupun masa yang akan datang.

Hasil penelitian menunjukan bahwa 100 persen variabel hasilnya $>0,3$ dan dinyatakan valid, dengan demikian seluruh item kuesioner dapat diikut sertakan dalam penelitian selanjutnya serta tingkat reliabilitas seluruh variabel tinggi karena nilai alpha cronbach $\geq 0,60$, sehingga dapat dinyatakan seluruh item dalam kuesioner adalah reliabel dan dapat dilanjutkan ke analisis selanjutnya.

Kesimpulan dari penelitian ini terdapat pengaruh strategi promosi terhadap loyalitas siswa/i pada SMP Muhammadiyah 4 Margahayu. Hal ini dibuktikan dari hasil pengukuran regresi sederhana terdapat pengaruh strategi promosi terhadap loyalitas siswa/i sebesar 50,8 persen serta nilai t hitung dan signifikan yang telah dijelaskan pada bab sebelumnya. Hasil Persentase dan pengujian tersebut menyimpulkan strategi promosi yang dilakukan SMP Muhammadiyah telah dinilai cukup baik karena dapat mempengaruhi setengah lebih dari penciptaan loyalitas siswa/i. sementara sisanya sebesar 49,2 persen dipengaruhi oleh variabel lain yang tidak diteliti dalam penelitian ini, misalnya kualitas pelayanan dan variabel lainnya.
\end{abstract}

Kata kunci : Strategi Promosi dan Loyalitas 


\section{PENDAHULUAN}

Perkembangan arus Globalisasi telah mampu mengubah dunia menjadi satu kota besar, dapat dikatakan demikian karena tidak ada pembatasan untuk memperoleh pengetahuan. Informasi yang berkembang sangat cepat. Dengan bantuan teknologi memungkinkan kita untuk mengetahui budaya, peristiwa serta apa yang sedang terjadi di ujung dunia. Pengetahuan yang kita terima dan peroleh tidak terlepas dari pendidikan yang telah kita lalui di masa sebelumnya. Pendidikan sangat penting guna membentuk karakter setiap individu yang akan bersaing dengan individu lainnya. Untuk memperoleh pengetahuan kita harus melewati beberapa jenjang pendidikan dari Sekolah Dasar, Sekolah Menengah Pertama, Sekolah Menengah Atas hingga Perguruan Tinggi.

Dewasa ini berkembang pemikiran di masyarakat bahwa sekolah yang baik atau sekolah favorit adalah sekolah yang memiliki bangunan yang luas dan jumlah siswa yang cukup banyak serta meluluskan siswa dengan nilai ujian yang memuaskan. Dengan demikian untuk menarik orang tua siswa agar menyekolahkan anaknya ke sekolah yang dimaksud pihak sekolah harus mampu membuat strategi promosi yang tujuan akhirnya mengajak orang tua dan siswa agar mau dan memiliki rasa loyal untuk bersekolah di sekolah tersebut.

Strategi promosi merupakan upaya menarik sebanyak mungkin orang agar mau menggunakan jasa atau barang yang dijual oleh suatu lembaga maupun perusahaan. Dalam hal ini dapat diibaratkan bahwa sekolah merupakan sebuah lembaga yang menjual jasa pendidikan yang bertujuan memperoleh siswa untuk tertarik dan loyal bersekolah di sekolah yang dimaksud.

Persaingan menarik siswa untuk bersekolah di masing-masing sekolah swasta begitu ketat terlebih Kecamatan Margahayu merupakan Kecamatan di Kabupaten Bandung yang berbatasan lansung dengan pusat kota yang sudah jelas terdapat sekolah- sekolah yang menjadi sekolah favorit. Berikut data jumlah siswa tingkat Sekolah Menengah Pertama se-Kecamatan Margahayu yang didapat dari salah satu halaman web Kementrian Pendidikan dan Kebudayaan.

\section{Tabel 1. Data Jumlah Siswa SMP Se Kec. Margahayu Kab.Bandung Mei} 2016

\begin{tabular}{|c|c|c|}
\hline NO & Nama Sekolah & $\begin{array}{c}\text { Jumlah Siswa } \\
\text { (Orang) }\end{array}$ \\
\hline 1. & SMPN 1 Margahayu & 1112 \\
\hline 2. & SMPN 2 Margahayu & 1237 \\
\hline 3. & SMPN 3 Margahayu & 1192 \\
\hline 4. & $\begin{array}{c}\text { SMPs } \\
\text { Muhammadiyah } 4 \\
\text { Margahayu }\end{array}$ & 552 \\
\hline NO & Nama Sekolah & $\begin{array}{c}\text { Jumlah Siswa } \\
\text { (Orang) }\end{array}$ \\
\hline 5. & $\begin{array}{l}\text { SMPs MA } \\
\text { Margahayu }\end{array}$ & 333 \\
\hline 6. & $\begin{array}{l}\text { SMPs KP } \\
\text { Margahayu }\end{array}$ & 650 \\
\hline 7. & SMPK 3 BinaBakti & 265 \\
\hline 8. & SMP IT Animah & 235 \\
\hline 9. & SMP Marhas & 92 \\
\hline 10. & $\begin{array}{c}\text { SMPs Angkasa } \\
\text { Lanud Sulaeman } \\
\end{array}$ & 315 \\
\hline \multicolumn{2}{|c|}{$\begin{array}{c}\text { Jumlah Siswa se Kec } \\
\text { Margahayu }\end{array}$} & 5983 Siswa \\
\hline
\end{tabular}

Sumber:http://referensi.data.kemdikbud.go.id/p d_index.php?level $=3 \& k o d e=020821 \& i d=6$ (05/01/2016/08:09)

Dari tabel di atas diketahui bahwa persaingan bukan hanya pada sekolah negeri saja tapi sekolah swasta mampu menyerap jumlah siswa yang tidak jauh beda atau lima puluh persen 
dari jumlah siswa di sekolah negeri. Dari tabel di atas dapat dilihat bahwa SMP Muhammadiyah 4 Margahayu memiliki jumlah siswa 552 orang, itu berarti 9 persen dari jumlah keseluruhan siswa se Kec. Margahayu dikuasai oleh SMP Muhammadiyah 4 Margahayu.

Strategi promosi yang saat ini dilakukan oleh pihak sekolah kebanyakan hanya berupa penyebaran brosur dan pemasangan spanduk pada saat tahun ajaran baru, dan hal tersebut dapat dinilai masih kurang efektif, karena kurang menyasar pasar secara menyeluruh sehingga kurang bisa memenuhi target capaian siswa baru yang akan melanjutkan ke sekolah menengah pertama. SMP Muhammadiyah 4 Margahayu merupakan sekolah swasta yang berada di Kecamatan Margahayu yang dalam kurun waktu sepuluh tahun ini mengalami perkembangan dalam hal peningkatan jumlah siswa baru disetiap tahun ajaran baru, Namun hal tersebut belum dapat dinilai memenuhi target capaian dari SMP Muhammadiyah 4 Margahayu, karena sebenarnya SMP Muhammadiyah 4 Margahayu memliki peluang yang sama dengan sekolah negeri maupun swasta lainnya hanya saja penerapan strategi promosi yang dilakukan harus tepat sasaran dan berbanding lurus dengan kualitas pengajar dan sarana prasarana yang terus diperbaiki dan dikembangkan. Dengan begitu perlu ada strategi promosi lain yang harus diterapkan oleh pihak sekolah khususnya SMP Muhammadiyah 4 Margahayu agar mampu meningkatkan jumlah siswa yang bersekolah disetiap ajaran baru.

$$
\text { Loyalitas siswa merupakan }
$$

kesetiaan seorang siswa sebagai konsumen utama atas dorongan keputusan orang tua siswa atau keluarga yang mempengaruhi untuk bersekolah disekolah tersebut. Loyalitas siswa dapat dilihat dari seberapa banyak anak dalam satu keluarga yang bersekolah disekolah yang sama.

Dalam hal ini SMP Muhammadiyah 4 Margahayu telah menggunakan dimensi strategi promosi yang tepat untuk meningkatan loyalitas siswa berupa peyebaran brosur, spanduk, iklan web dan lainnya, namun masih belum dapat dikatakan maksimal karena data menunjukan SMP Muhammadiyah 4 Margahayu hanya mampu menyerap 9 persen siswa yang ada di Kec. Margahayu.

Pada tahun ajaran baru berikutnya setiap Lembaga Pendidikan akan selalu mencari cara bagaimana untuk mempromosikan sekolah sekolahnya agar mampu menyerap siswa sesuai dengan yang diharapkan, begitu pula dengan SMP Muhammdiyah 4 Margahayu harus mampu meningkatkan kembali kualitas pelayanan dan strategi promosi agar tercipta loyalitas siswa sesuai yang diharapkan.

Dengan demikian dapat disimpulkan bahwa persaingan bukan hanya terjadi pada perusahaan barang yang mejual produk untuk menghasilkan profit, namun di lembaga pendidikan juga memiliki daya saing yang tidak kalah ketat. Strategi promosi yang baik akan mempengaruhi peningkatan siswa/i setiap tahun ajaran baru.

\section{KERANGKA TEORITIS \& HIPOTESIS \\ Loyalitas Konsumen \\ Griffin \\ kembali mengemukakan pendapatnya tentang loyalitas, Griffin (2005: 31),}


"komitmen pelanggan bertahan secara mendalam untuk berlangganan kembali atau melakukan pembelian. Konsumen yang loyal merupakan asset yang tidak ternilai bagi perusahaan"

Kotler dan Keller (2005:138) yang dikemukakan oleh Oliver, bahwa loyalitas sebagai komitmen yang dipegang secara mendalam untuk membeli atau mendukung kembali produk atau jasa yang dikuasai di masa depan meski pengaruh situasi dan usaha pemasaran berpotensi menyebabkan pelanggan beralih. Loyalitas merupakan suatu bentuk kesetiaan dan komitmen dari seorang konsumen yang dapat dilihat dari seberapa sering ia menggunakan produk atau jasa, loyalitas hanya dapat dilihat jika konsumen tersebut memiliki kekebalan terhadap produk lain.

\section{Jenis-Jenis Loyalitas}

Menurut Jill Griffin (2005:22) terdapat empat jenis loyalitas yang muncul bila keterikatan rendah dan tinggi diklasifikasi-silang dengan pola pembelian ulang, yang rendah dan tinggi.

Adapun jenis-jenis loyalitas konsumen yaitu :

1. Tanpa Loyalitas

Untuk berbagai alasan tertentu, ada beberapa konsumen yang tidak mengembangkan loyalitas atau kesetiaan kepada suatu produk maupun jasa tertentu. Tingkat keterikatan yang rendah dengan tingkat pembelian ulang yang rendah menunjukkan absennya suatu kesetiaan. Pada dasarnya, suatu usaha harus menghindari kelompok no loyality ini untuk dijadikan target pasar, karena mereka tidak akan menjadi konsumen yang setia.

2. Loyalitas yang lemah (Inertia Loyality)
Inertia loyality merupakan sebuah jenis loyalitas konsumen yang dimana adanya keterikatan yang rendah dengan pembelian ulang yang tinggi. Konsumen yang memiliki sikap ini biasanya membeli berdasarkan kebiasaan. Dasar yang digunakan untuk pembelian produk atau jasa disebabkan oleh faktor kemudahan situsional. Kesetiaan semacam ini biasanya banyak terjadi terhadap produk atau Jasa yang sering dipakai. Contoh dari kesetiaan ini terlihat dari kegiatan pembelian bensin yang dilakukan konsumen di dekat daerah rumahnya dan sebagainya. Pembeli dengan loyalitas yang lemah rentan beralih ke produk pesaing yang dapat menunjukkan manfaat yang jelas. Meskipun demikian, perusahaan masih memiliki kemungkinan untuk mengubah jenis loyalitas ini ke dalam bentuk loyalitas yang lebih tinggi melalui pendekatan yang aktif ke pelanggan dan peningkatan nilai perbedaan positif yang diterima konsumen atas produk maupun jasa yang ditawarkan kepadnya dibandingkan dengan yang ditawarkan para pesaing lain. Hal ini dapat dilakukan melalui peningkatan keramahan dalam pelayanan dan fasilitas yang diberikan kepada konsumen.

3. Loyalitas Tersembunyi (Laten Loyality)

Jenis loyalitas tersembunyi merupakan sebuah kesetiaan atau keterikatan yang relatif tinggi yang disertai dengan tingkat pembelian ulang yang rendah. Konsumen yang mempunyai sikap laten loyality pembelian ulang juga didasarkan pada pengaruh faktor situasional daripada sikapnya. Sebagai contoh, seorang suami menyukai masakan Eropa, tetapi 
mempunyai istri yang kurang menyukai masakan Eropa. Maka suami tersebut hanya sesekali saja mengunjungi restoran Eropa dan lebih sering pergi ke restoran yang dimana masakan yang ditawarkan dapat dinikmati bersama.

4. Loyalitas Premium (Premium

\section{Loyalty)}

Loyalitas ini merupakan yang terjadi bilamana suatu tingkat keterikatan tinggi yang berjalan selaras dengan aktivitas pembelian kembali. Setiap perusahaan tentunya sangat mengharapkan kesetiaan jenis ini dari setiap usaha preference yang tinggi. Contoh jenis loyalty premium adalah rasa bangga yang muncul ketika konsumen menemukan dan menggunakan produk atau jasa tersebut dan dengan senang hati membagi pengetahuan dan merekomendasikannya kepada teman, keluarga maupun orang lain.

\section{Karakteristik Loyalitas Konsumen}

Loyalitas pelanggan merupakan ukuran yang dapat diandalkan untukmemprediksi pertumbuhan penjualan dan loyalitas pelanggan juga dapatdidefinisikan berdasarkan perilaku pembelian yang konsisten (Griffin,2005:31).

Berikut ini ada lima karakteristik loyalitas konsumen yang perludiperhatikan yaitu :

1. Melakukan pembelian ulang secara teratur

Konsumen melakukan pembelian secara contineu pada suatu produk tertentu. Contoh: pencipta motor Harley Davidson akan membeli motor Harley baru jika ada model Harley Davidson yang terbaru, bahkan tidak hanya membeli tetapi mereka juga mengeluarkan uang tambahan untuk mengubahnya sesuai dengan keinginan mereka.

2. Membeli antarlini produk dan jasa

Konsumen tidak hanya membeli jasa dan produk utama tetapi konsumen juga membeli lini produk dan jasa dari perusahaan yang sama.

3. Mereferensikan kepada orang lain.

Dimana konsumen melakukan komunikasi dari mulut ke mulut (word of mouth) berkenan dengan produk tersebut.

4. Menunjukkan kekebalan terhadap tarikan dari pesaing.

Konsumen menolak untuk menggunakan produk atau jasa alternatif yang ditawarkan oleh pesaing.

\section{Tahap Pembentukan Loyalitas Konsumen}

Konsumen yang loyal tentu tidak terbentuk begitu saja, namun melalui beberapa proses tahapan, Griffin (2003) membagi tahapan loyalitas sebagai berikut:

\section{Suspect}

Suspect adalah orang yang mungkin membeli produk atau jasa anda. Kita menyebutnya suspectkarena kita percaya, atau "menyangka" mereka akan membeli, tetapi kita masih belum cukup yakin.

\section{Prospect}

Prospect adalah orang yang membutuhkan produk atau jasa anda dan memiliki kemampuan membeli. Meskipun prospect belum membeli dari anda, ia mungkin telah mendengar tentang anda, membaca tentang anda, atau ada seseorang yang merekomendasikan anda kepadanya. Prospectmungkin tahu siapa, di mana, dan apa yang anda jual, tetapi mereka masih belum membeli dari anda. 


\section{Disqualified Prospect}

\section{Disqualified}

prospect adalah prospect yang telah cukup anda pelajari untuk menetahui bahwa mereka tidak membutuhkan, atau tidak memiliki kemampuan membeli produk anda.

\section{First time Customer}

First time customer adalah orang yang telah membeli dari anda satu kali. Orang tersebut bisa jadi merupakan pelangan anda sekaligus juga pelanggan pesaing anda.

5. Repeat Customer

Repeat customer adalah orang yang telah membeli dari anda dua kali atau lebih. Mereka mungkin telah membeli produk yang sama dua kali atau membeli dua produk tau jasa yang berbeda pada dua kesempatan atau lebih.

\section{Client}

Client membeli apapun yang anda jual dan dapat ia gunakan. Orang ini membeli secara teratur. Anda memiliki hubungan yang kuat dan berlanjut, yang menjadikannya kebal tehadap tarikan pesaing.

\section{Advocate}

Seperti client,

advocate membeli apapun yang anda jual dan dapat ia gunakan serta membelinya secara teratur. namun Advocate juga mendorong orang lain untuk membeli dari anda. Ia membicarakan anda, melakukan pemasaran bagi anda, dan membawa pelanggan anda

Keuntungan dari Konsumen yang Loyal

Menurut Kotler, Hayes, dan Bloom (dalam Buchari Alma 2002:275) ada enam alasan mengapa perusahaan harus menjaga dan mempertahankan konsumennya:
1. Pelanggan yang sudah ada memiliki prospek yang lebih besar untuk memberikan keuntungan kepada perusahaan.

2. Biaya yang dikeluarkan perusahaan dalam menjaga dan memperthankan pelanggan yang sudah ada, jauh lebih kecil daripada mencari pelanggan baru.

3. Pelanggan yang percaya kepada suatu lembaga dalam suatu urusan bisnis, cenderung akan percaya juga pada urusan bisnis yang lain.

4. Jika sebuah perusahaan lama memiliki banyak pelanggan lama, maka perusahaan tersebut akan mendapatkan keuntungan karena adanya efisiensi. Pelanggan lama sudah barang tentu tidak akan banyak lagi tuntutan, perusahaan cukup menjaga dan mempertahankan mereka. Untuk melayani merekabisa digunakan karyawan-karyawan baru dalam rangka melatih mereka, sehingga biaya pelayanan lebih murah

5. Pelanggan lama tentunya telah banyak memiliki pengalaman positifyang berhubungan dengan perusahaan, sehingga mengurangi biaya psikologis dan sosialisasi.

6. Pelanggan lama akan berusaha membela perusahaan, dan mereferensikan perusahaan tersebut kepada teman-teman maupun lingkungannya.

\section{Strategi Promosi}

Menurut Kotler (2000:91),
strategi adalah "Suatu rencana
permainan untuk mencapai sasaran
yang dinginkan dari suatu unit bisnis".
Promosi menurut Alma
(2006:179) adalah : "Promosi adalah sejenis komunikasi yang memberi penjelasan dan meyakinkan calon konsumen mengenai barang dan jasa dengan tujuan untuk memperoleh 
perhatian, mendidik, mengingatkan dan meyakinkan calon konsumen".

Menurut Martin L. Bell dalam Swastha dan Irawan (2005:349) promosi adalah semua jenis kegiatan pemasaran yang ditujukan untuk mendorong permintaan. Promosi adalah arus informasi atau persuasi satu arah yang dibuat untuk mengarahkan seseorang atau organisasi kepada tindakan yang menciptakan pertukaran dalam pemasaran.

Strategi promosi menurut Moekijat (2000 : 443) : "strategi promosi adalah kegiatan perusahaan untuk mendorong penjualan dengan mengarahkan komunikasi-komunikasi yang meyakinkan kepada para pembeli."

Promosi merupakan alat komunikasi dan penyampaian pesan bersifat memberitahukan, membujuk, mengingatkan kembali kepada konsumen, para perantara atau kombinasi keduanya. Dalam promosi terdapat beberapa unsur yang mendukung jalannya sebuah promosi tersebut yang biasa disebut bauran promosi.

\section{Periklanan Jasa Pendidikan}

Iklan merupakan suatu bentuk komunikasi yang dilakukan oleh perusahaan guna untuk memperkenalkan, mengingatkan kembali kepada masyarakat luas tentang suatu produk. Kotler dan Keller (2005 : 277) menyatakan bahwa iklan adalah segala bentuk presentasi non- pribadi dan promosi gagasan, barang atau jasa oleh sponsor tertentu yang harus dibayar.

Sementara munurut Monle Lee dan Carla Johnson Periklanan adalah komunikasi komersil dan nonpersonal tentang sebuah organisasi dan produk-produknya yang ditransmisikan ke suatu khalayak target melalui media bersifat missal. (prinsipprinsip periklanan dalam perspektif global.

Adapun fungsi utama iklan adalah :

- Informative; menginformasikan khalayak mengenai seluk beluk produk.

- $\quad$ Persuading; mempengaruhi

khalayak untuk membeli.

Reminding; menyegarkan

informasi yang telah diterima khalayak.

Entertainment; menciptakan suasana yang menyenangkan sewaktu khalayak menerima dan mencerna informasi.

Dari pengertian diatas dapat dinyatakan bahwa iklan merupakan suatu bentuk pesan yang dipersiapkan oleh perusahaan melalui beberapa saluran media guna menyampaikan promosi, gagasan dan ide pada suatu produk yang akan di pasarkan.

\section{Promosi Jasa Pendidikan}

Kotler dan Keller (2005:298) menyatakan bahwa promosi merupakan unsur utama dalam kampanye pemasaran, adalah berbagai kumpulan alat- alat insentif, yang sebagian besar berjangka pendek, yang dirancang untuk merangsang pembelian produk atau jasa tertentu dengan lebih cepat dan lebih besar oleh konsumen atau pedagang.

Sedangkan pengertian promosi menurut Buchari Alma (2006 : 179) adalah : "Promosi adalah sejenis komunikasi yang memberi penjelasan dan meyakinkan calon konsumen mengenai barang dan jasa dengan tujuan untuk memperoleh perhatian, mendidik, mengingatkan dan meyakinkan calon konsumen". 
Promosi yang dimaksud adalah promosi penjualan yang menjadi bagian dari indikator dari strategi promosi, namun penelitian ini lebih focus pada lembaga pendidikan yang berupa jasa maka promosi yang akan diteliti bagian dari promosi jasa pendidikan yang mengacu pada promosi penjualan tersebut. Promosi merupakan kegiatan yang berbentuk rancangan, kumpulan dari alat- alat yang dilakukan oleh perusahaan untuk merangsang konsumen dan meyakinkan calon konsumen terhadap produk yang dimiliki oleh perusahaan.

\section{Public Relation Masyarakat)}

Kottler dan Keller (2005:306) menyatakan bahwa public relation atau Hubungan Masyarakat (humas) meliputi berbagai program yang dirancang untuk mempromosikan atau melindungi citra perusahaan atau masing- masing produknya.. Selain itu Kottler dan Keller (2005:306) menyatakan masyarakat (public) adalah setiap kelompok yang memiliki kepentingan dalam atau pengaruh terhadap kempuan suatu perusahaan mencapai tujuannya saat ini atau pada masa mendatang.

Hubungan masyarakat atau sering dikenal dengan public relation merupakan sebuah system dan program yang dirancang oleh perusahaan untuk menjadi penyelenggara pelayanan bagi konsumen dan masyarakat yang ada disekitar perusahaan, humas berperan penting untuk memperkenalkan perusahaan secara lebih dekat kepada masyarakat luas.

\section{METODE PENELITIAN}

Metode penelitian yang digunakan adalah metode deskriptif.
Menurut M. Nazir (2005), metode deskriptif adalah suatu metode dalam meneliti status kelompok manusia, suatu objek, suatu setting kondisi, suatu system pemikiran, ataupun suatu kelas peristiwa pada masa sekarang.

Studi kasus merupakan penelitian yang terperinci mengenai suatu obyek tertentu selama kurun waktu tertentu, termasuk lingkungan dan kondisi masa lalunya dengan cukup mendalam dan menyeluruh. Tujuan dari penelitian deskripsi ini yang mengambil penelitian dengan metode studi kasus adalah membuat deskripsi, gambaran, yang terjadi saat sekarang, masa lalu maupun masa yang akan datang.

\section{Populasi Dan Sampel Penelitian}

\section{a. Populasi}

Menurut Sugiyono (2009) populasi adalah wilayah generalisasi yang terdiri dari atas objek / subjek yang mempunyai kualitas dan karakteristik tertentu yang ditetapkan oleh peneliti untuk dipelajari dan kemudian ditarik kesimpulannya.

Dari penjelasan diatas maka yang akan menjadi populasi adalah seluruh siswa/i kelas VIII SMP Muhammadiyah 4 Margahayu. Data tersebut didapatkan dari bagian TU dan Administrasi disekolah tersebut. Populasi ditentukan berdasarakan alasan karena kelas VIII dapat mewakili kreteria responden dalam mengikuti perkembangan strategi promosi yang dilakukan oleh SMP Muhammadiyah 4 Margahayu yang berpengaruh pada loyalitas konsumen. Berikut data jumlah siswa kelas VIII SMP Muhammadiyah 4 Margahayu :

Tabel 2 Data Jumlah Siswa Kelas VIII SMP Muhammadiyah 4 Margahayu 


\begin{tabular}{|c|c|}
\hline Kelas VIII & $\begin{array}{c}\text { Jumlah Siswa } \\
\text { ( Orang) }\end{array}$ \\
\hline A & 35 \\
\hline B & 36 \\
\hline C & 35 \\
\hline D & 35 \\
\hline E & 35 \\
\hline F & 36 \\
\hline $\begin{array}{l}\text { Jumlah } \\
\text { Seluruh } \\
\text { (Orang) }\end{array}$ & $\mathbf{2 1 2}$ \\
\hline
\end{tabular}

Sumber : Bagian TU dan Administrasi

\section{b. Sampel}

Menurut Sugiyono (2016:81), sampel adalah bagian dari jumlah dan karakteristik yang dimiliki oleh populasi tersebut. Jadi sampel adalah sebagai atau wakil populasi yang diteliti. Dalam penelitian ini metode pengambilan sampel yang digunakan adalah metode pendekatan Stratified Random Sampling, sampel ditarik dengan memisahkan elemen-elemen dari populasi dalam kelompokkelompok yang tidak overlapping yang disebut strata, dan kemudian memilih sebuah sampel secara random dari tiap stratum. Dalam penelitiaan ini, Peneliti akan mengambil sampel dari siswa/i dan orang tua siswa kelas VIII yang datanya telah dipeloreh dari sekolah tersebut. Maka dari itu peneliti menggunakan metode pengambilan sampel dengan teknik stratified random sampling.

Pengambilan sampel pada penelitian ini menggunakan rumus Slovin dimana:

$$
n=\frac{N}{1+N e^{2}}
$$

Ket : $n$ : jumlah sampel; $\mathrm{N}$ : jumlah populasi; e: batas toleransi kesalahan (error tolerance)

Dari rumus tersebut dapat dihitung sebagai berikut:

$$
\begin{aligned}
& n=\frac{N}{1+N e^{2}} \\
& \mathrm{n}=\frac{212}{\left(1+212 \times 0,05^{2}\right)} \\
& =138,56 \text { responden. }
\end{aligned}
$$

Atau dibulatkan menjadi 139 responden.

Dalam hal ini peneliti akan mengambil sampel dari kelas VIII SMP Muhammadiayh 4 Margahayu, dan akan mengalokasikan jumlah sampel setiap kelas dengan menggunakan metode pendekatan proportionate stratified random sampling agar didapat alokasi sampel tiap kelas sebagai berikut :

Tabel 3. Alokasi Jumlah Sampel

\begin{tabular}{|c|c|}
\hline Kelas VIII & $\begin{array}{c}\text { Jumlah Siswa } \\
\text { (orang) }\end{array}$ \\
\hline A & 23 \\
\hline B & 24 \\
\hline C & 23 \\
\hline D & 23 \\
\hline E & 23 \\
\hline F & 23 \\
\hline $\begin{array}{c}\text { Jumlah } \\
\text { (Orang) }\end{array}$ & $\mathbf{1 3 9}$ \\
\hline
\end{tabular}

Sumber: data sekunder yang diolah tahun 2016

\section{Metode Analisis Data Uji Validitas}

Validasi berarti instrumen tersebut dapat digunakan untuk mengukur apa yang seharusnya diukur. (Sugiyono; 2011, 121). Dapat disimpulkan bahwa kuesioner yang dianggap valid apabila jawaban dari kuesioner tersebut ada keterkaitan 
dengan butir pertanyaan yang ada di kuesioner.

Ukuran keterkaitan antar butir pernyataan ini umumnya ditandai dengan korelasi/ hubungan jawaban antar pernyataan. Pernyataan yang memiliki korelasi rendah, dinyatakan tidak valid. Metode yang digunakan untuk memberikan penilaian terhadap validitas kuisioner adalah korelasi produk momen (Moment Product Correlation).

Korelasi produk moment untuk mencari pengaruh dan membuktikan hipotesis adanya pengaruh variable $X$ terhadap variabel $\mathrm{Y}$, digunakan rumus sebagai berikut (Sugiyono):

$\mathrm{r} x \mathrm{y}=$ $\mathrm{n} \Sigma \mathrm{XY}-\Sigma \mathrm{X} \Sigma \mathrm{Y}$ $\left.\mathrm{Y})^{2}\right]$ $\sqrt{\left[n \Sigma X^{2-}(\Sigma X)^{2} \cdot n \Sigma Y^{2}-(\Sigma\right.}$

Keterangan :

$\mathrm{r} x y=$ koefisien korelasi yang dicari

$\mathrm{X}=$ skor $/$ nilai yang diterima konsumen

$\mathrm{Y}=$ skor $/$ nilai yang diharapkan konsumen

$\mathrm{N}=$ jumlah responden

Penjelasan : Nilai $\mathrm{r}$ xy bervariasi dari 1 s.d +1 , atau secara matematik dapat ditulis menjadi $-1<\mathrm{r}$ xy $<+1$, atau dapat disebutkan sebagai berikut:

$\mathrm{r} x \mathrm{xy}=0$ atau mendekati nol, menyatakan korelasi yang sangat lemah dan tidak ada korelasi sama sekali diantara dua variabel.

$\mathrm{r}$ xy $=+1$, menyatakan bahwa korelasi antara dua variabel dikatakan positif/ baik dan sangat kuat sekali atau dengan kata lain korelasi positif sempurna.

$\mathrm{r} x \mathrm{y}=-1$, menyatakan bahwa korelasi antara dua variabel dikatakan negatif / buruk dan sangat kuat sekali atau dengan kata lain korelasi negatif sempurna.

Menurut Sugiono (2012:126) bahwa "Ketentuan validitas instrumen yang kuat, apabila nilai korelasi (r) dihitung lebih besar dari $r$ kritis yaitu 0,3. Selain ini Sugiyono menambahkan bahwa bila korelasi tiap faktor adalah positif dan besarnya 0,3 ke atas maka faktor tersebut merupakan construct yang kuat".

\section{Uji Reliabilitas}

Realibilitas adalah suatu instrumen cukup dapat dipercaya untuk digunakan sebagai alat pengumpul data karena instrumen tersebut sudah baik. Realibel artinya dapat dipercaya, jadi dapat diandalkan. (Arikunto: 2010, hal. 221).

Instrumen yang realibel adalah instrumen yang bila digunakan beberapa kali untuk mengukur obyek yang sama, akan menghasilkan data yang sama. (Sugiyono: 2011, 121)

Uji reliabilitas dilakukan dengan menggunakan metode Alpha Cronbach's yang diukur berdasarkan skala Alpha Cronbach's berupa angka 0 sampai 1,0. Sugiyono menyatakan bahwa jika skala dikelompokan kedalam 5 kelas, dengan range yang sama, maka ukuran kemantapan Alpha Cronbach's dapat diinterpretasikan sebagai berikut :

1. Nilai 0,00 s.d. 0,20 berarti kurang reliabel

2. Nilai 0,21 s.d. 0,40 berarti agak reliabel

3. Nilai 0,41 s.d. 0,60 berarti cukup reliabel

4. Nilai 0,61 s.d. 0,80 berarti reliabel

5. Nilai 0,81 s.d. 1,00 berarti sangat reliabel

Menurut Sugiyono (2004) bahwa "reliabilitas suatu konstruk dinyatakan baik apabila memiliki nilai Alpha Cronbach's lebih besar dari 0,60". Maka pengujian reliabilitas instrumen dalam sebuah penelitian 
dilakukan karena keterhandalan instrumen berkaitan dengan taraf kepercayaan terhadap instrumen penelitian tersebut.

\section{Skala Sikap}

Skala sikap dalam penelitian ini digunakan untuk mengetahui sikap konsumen terhadap strategi promosi dan loyalitas konsumen (siswa)di SMP Muhammadiyah 4 Margahayu Kab. Bandung. Skala yang digunakan dengan menggunakan 5 pilihan yaitu sangat setuju $=5$, setuju $=4$, ragu ragu $=3$, tidak setuju $=2$, dan sangat tidak setuju $=1$. Kemudian akan dilakukan pembagian skor sikap menurut cara penilaian model skala likert yaitu dengan menggunakan skor $\mathrm{T}$ dengan rumus :

$$
T=50+10\left(\frac{X-x}{s d}\right)
$$

Dimana :

$\mathrm{X}=$ skor responden pada skala sikap $\mathrm{x}=$ Mean (rata - rata) skor kelompok $\mathrm{sd}=$ standar deviasi skor kelompok

Setelah diperoleh skor $\mathrm{T}$ untuk setiap variabel selanjutnya dapat dikelompokkan menjadi 2 kelompok yaitu : Skor T < Rata - rata :

Unvafavorable atau responden cenderung bersikap negatif (tidak mendukung) terhadap isi pernyataan variabel yang diamati. Skor $\mathrm{T} \geq$ Rata rata : Favorable atau responden cenderung bersikap positif (mendukung) terhadap isi pernyataan variabel yang diamati.

\section{Uji Statistik}

\section{Transformasi Data}

Data yang didapatkan dari skala ordinal harus dinaikan terlebih dahulu ke dalam skala interval . untuk merubah atau menaikan pengukuran tersebut digunakan Metode Succesive Interval, selanjutnya entri data tersebut dimasukkan ke dalam perhitungan dengan bantuan komputer menggunakan sofware succesive interval. Secara ringkas, langkahnya sebagai berikut :

1. Buka Office dan pilih Ms.Excel lalu tampilkan data jawaban dari kuesioner yang disebarkan kepada responden pada sheet 1 .

2. Klik Add Ins

3. Klik file succesive Interval

4. Klik data Range

5. Blok data/ jawaban dari responden (ordinal) yang akan dirubah menjadi skala interval.

6. Ketik angka 5 pada kolom Max. Value lalu Enter

7. Klik Ok pada Display Summary

8. Pindahkan darta yang sudah di blok di sheet 2

9. Buat blok sesuai jumlah kolom dan spasi sesuai jumlah data yang dirubah datanya lalu tekan Enter.

Data berupa angka dari responden semula skala ordinal sekarang berubah menjadi data skala interval.

\section{Analisis Regresi}

Analisis regresi merupakan suatu analisa yang digunakan untuk mengetahui perubahan dua variabel atau lebih. Sehingga dapat memprediksi kondisi suatu variabel apabila variabel lain diketahui.

Pada persamaan regresi yang digunakan adalah persamaan regresi linear sederhana, karena didasarkan pada jumlah variabel yang lebih dari satu variabel yaitu satu variabel $X$ dan satu variabel Y.

Persamaan umum regresi linear sederhana adalah : $\mathbf{Y}=\mathbf{a}+\mathbf{b X}$

Keterangan: 
$\mathrm{Y}=$ Subjek dalam variabel dependen yang diprediksikan

a = harga $\mathrm{Y}$ ketika $\mathrm{X}=0$ (konstan)

$\mathrm{b}=$ angka arah atau koefisien regresi, yang menunjukan angka peningkatan ataupun penurunan variabel dependen yang didasarkan pada perubahan variabel independen. Bila (+) arah garis naik, bila (-) maka arah garis turun.

$\mathrm{X}=$ subjek pada variabel independen yang mempunyai nilai tertentu.

Selain itu nilai a dan b dapat dicari dengan rumus berikut :

$$
\begin{aligned}
& \mathrm{a}=(\Sigma \mathrm{Y})\left(\Sigma \mathrm{X}^{2}\right)-(\Sigma \mathrm{X}) \\
& \text { ( } \Sigma X Y) \\
& \text { n } \Sigma X^{2}-(\Sigma X)^{2} \\
& \mathrm{~b}=\mathrm{n} \Sigma \mathrm{XY}-(\Sigma \mathrm{X})-
\end{aligned}
$$$$
(\Sigma Y)
$$

$$
\mathrm{n} \Sigma \mathrm{X}^{2}-(\Sigma \mathrm{X})^{2}
$$

\section{Koefisien Determinasi}

Koefisien

Determinasi

bertujuan untuk menghitung besarnya pengaruh variable $(\mathrm{X})$ yang dalam penelititan ini adalah Strategi promosi terhadap variable (Y) yang dalam penelitian ini adalah loyalitas konsumen (siswa), dan nilai koefisien determinasi dihitung menggunakan:

\section{Rumus 3.4 \\ $\mathrm{KD}=\mathbf{r}^{2} \times 100 \%$}

Keterangan:

$\mathrm{KD}=$ koefisien

determinasi korelasi

$$
\mathrm{r}=\text { nilai koefisien }
$$

\section{Pengujian Hipotesa}

Pengujian ini membuktikan Ho atau $\mathrm{H} 1$ yang akan diterima. Jika $\mathrm{H} 1$ diterima maka Ho ditolak, dan begitu juga sebaliknya. Untuk menguji hipotesis yang telah diajukan yaitu strategi promosi terhadap loyalitas konsumen (siswa), digunakan pengujian hipotesis sebagai berikut:

$\mathrm{H} 0=$ Tidak ada pengaruh antara Strategi Promosi terhadap Loyalitas Siswa di SMP Muhammadiyah 4 Margahayu.

H1 = Ada pengaruh yang signifikan antara Strategi Promosi terhadap Loyalitas Siswa/I untuk bersekolah di SMP Muhammadiyah 4 Margahayu.

\section{Uji $t$ hitung}

Menurut Sugiyono untuk hasi $t$ hitung dapat disimpulkan jika:

A nilai $t$ hitung $\geq$ nilai $\mathrm{t}$ table maka Ho ditolak, berarti $\mathrm{H} 1$ diterima, atau strategi promosi berpengaruh terhadap loyalitas konsumen (siswa).

B nilai $t$ hitung $\leq$ nilai t table maka Ho diterima, berarti H1 ditolak, atau strategi promosi tidak berpengaruh terhadap loyalitas konsumen (siswa).

Adapun penghitungannya menggunakan rumus :

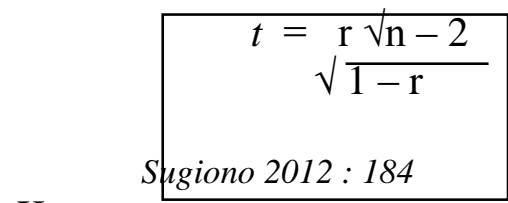

Keterangan:

$$
\begin{aligned}
& \mathrm{r}=\text { nilai korelasi } \\
& \mathrm{n}=\text { jumlah sampel }
\end{aligned}
$$

\section{ANALISIS DATA \\ PEMBAHASAN \\ Profil Responden}

Responden yang menjadi sampel dalam penelitian ini sebanyak 139 responden. Responden tersebut ialah siswa kelas VIII di SMP Muhammadiyah 4 Margahayu dan orang tua/ wali siswa tersebut. Gambaran mengenai responden yang menjadi sampel penelitian adalah sebagai berikut : 
Tabel 4. Karakteristik Responden

atau kuesioner mengenai loyalitas berdasarkan Jenis Kelamin dan Kelas

\begin{tabular}{|c|c|c|c|}
\hline Kelas & L (orang) & $\mathbf{P}$ (orang) & $\begin{array}{l}\text { ProfähResponden } \\
\text { (orang) Responden }\end{array}$ \\
\hline A & 9 & 15 & sañtpel dalam penelitian ini sebanyak \\
\hline $\mathrm{B}$ & 11 & 12 & 1393 responden. Responden tersebut \\
\hline $\mathrm{C}$ & 8 & 15 & ialæh siswa kelas VIII di SMP \\
\hline D & 11 & 12 & Mughammadiyah 4 Margahayu dan \\
\hline E & 8 & 15 & orang tua/ wali siswa tersebut. \\
\hline$F$ & 9 & 14 & Gambaran mengenai responden yang \\
\hline Total & 56 & 83 & solar samper $\mathrm{p}$ \\
\hline Presentase & $40 \%$ & $60 \%$ & $100 \%$ \\
\hline
\end{tabular}

Sumber : Data Primer diolah tahun 2016

Dari tabel di atas diperoleh gambaran atau data responden berdasarkan jenis kelamin di masing masing kelas. Responden laki - laki sebanyak 56 orang atau sebesar 40 persen responden laki-laki sementara responden perempuan sebanyak 83 orang atau sebesar 60 persen. Karena penelitian ini memiliki dua responden di mana responden pertama adalah siswa dan responden ke dua adalah orang tua/ wali siswa tersebut. Berikut gambaran responden ke dua :

Tabel 4. Karakteristik Responden orang tua siswa berdasarkan Jenis Kelamin

\begin{tabular}{|c|c|c|c|}
\hline No & $\begin{array}{c}\text { Jenis } \\
\text { Kelamin }\end{array}$ & $\begin{array}{c}\text { Jumlah } \\
\text { (Orang) }\end{array}$ & Presentase \\
\hline 1 & Pria & 93 & $67 \%$ \\
\hline 2 & Wanita & 46 & $33 \%$ \\
\hline \multicolumn{2}{|c|}{ Total (Orang) } & 139 & $100 \%$ \\
\hline
\end{tabular}

Sumber : Data Primer diolah tahun 2016

Tabel di atas diperoleh gambaran atau data responden kedua berdasarkan jenis kelamin. Responden pria sebanyak 93 orang atau sebesar 67 persen responden laki-laki sementara responden wanita sebanyak 46 orang atau sebesar 33 persen. Responden ke dua adalah orang tua / wali siswa yang mengisi angket

\section{Tabel 5. Karakteristik Responden} berdasarkan Jenis Kelamin dan Kelas Sumber : Data Primer diolah tahun 2016

\begin{tabular}{|c|c|c|c|}
\hline Kelas & $\begin{array}{c}\text { L } \\
\text { (orang) }\end{array}$ & $\begin{array}{c}\text { P } \\
\text { (orang) }\end{array}$ & $\begin{array}{c}\text { Jumlah } \\
\text { (orang) }\end{array}$ \\
\hline A & 9 & 15 & 24 \\
\hline B & 11 & 12 & 23 \\
\hline C & 8 & 15 & 23 \\
\hline D & 11 & 12 & 23 \\
\hline E & 8 & 15 & 23 \\
\hline F & 9 & 14 & 23 \\
\hline Total & $\mathbf{5 6}$ & $\mathbf{8 3}$ & $\mathbf{1 3 9}$ \\
\hline Presentase & $\mathbf{4 0} \%$ & $\mathbf{6 0} \%$ & $\mathbf{1 0 0} \%$ \\
\hline
\end{tabular}

Dari tabel di atas diperoleh gambaran atau data responden berdasarkan jenis kelamin di masing masing kelas. Responden laki - laki sebanyak 56 orang atau sebesar 40 persen responden laki-laki sementara responden perempuan sebanyak 83 orang atau sebesar 60 persen. Karena penelitian ini memiliki dua responden di mana responden pertama adalah siswa dan responden ke dua adalah orang tua/ wali siswa tersebut. Berikut gambaran responden ke dua :

\section{Tabel 4. Karakteristik Responden} orang tua siswa berdasarkan Jenis Kelamin

\begin{tabular}{|l|l|l|l|}
\hline No & Jenis & Jumlah & Presentase \\
\hline
\end{tabular}




\begin{tabular}{|c|c|c|c|}
\hline & Kelamin & (Orang) & \\
\hline 1 & Pria & 93 & $67 \%$ \\
\hline 2 & Wanita & 46 & $33 \%$ \\
\hline \multicolumn{2}{|c|}{ Total (Orang) } & 139 & $100 \%$ \\
\hline
\end{tabular}

Sumber : Data

Primer diolah tahun 2016

Tabel di atas diperoleh gambaran atau data responden kedua berdasarkan jenis kelamin. Responden pria sebanyak 93 orang atau sebesar 67 persen responden laki-laki sementara responden wanita sebanyak 46 orang atau sebesar 33 persen. Responden ke dua adalah orang tua / wali siswa yang mengisi angket atau kuesioner mengenai loyalitas siswa/i (konsumen).

\section{Uji Hipotesis}

\section{Uji Signifikan (Uji f)}

Uji signifikan digunakan untuk mengetahui hubungan linear atau tidak antara variabel $\mathrm{X}$ terhadap variabel $\mathrm{Y}$. Hal ini dilakukan sebagai syarat dilakukannya uji pengaruh, artinya hubungan kedua variabel linear. Maka uji pengaruh dapat dilakukan dan sebaliknya apabila kedua variabel tersebut tidak linear, maka uji pengaruh tidak dapat dilakukan.

1. Hipotesis

Pengujian hipotesis dimaksudkan sebagai cara untuk menentukan apakah suatu dugaan hipotesis tersebut sebaiknya diterima atau ditolak.

Asumsi / dasar pengambilan keputusan yang digunakan adalah:

Jika probabilitas $>0.05=$ tidak signifikan (menerima Ho). Artinya terdapat pengaruh yang signifikan antara variabel strategi promosi terhadap loyalitas siswa/I pada SMP Muhammadiyah 4 Margahayu.

Jika probabilitas $<0.05=$ signifikan (menolak Ho). Artinya variabel strategi promosi linear terhadap loyalitas
siswa/I pada SMP Muhammadiyah 4 Margahayu.

2. Kesimpulan

Nilai sig-F $0.000<0.05$. Disimpulkan Ho ditolak, artinya strategi promosi mempunyai linear (berpengaruh) terhadap loyalitas siswa/i pada SMP Muhammadiyah 4 Margahayu. Artinya hubungan kedua variabel tersebut bisa dilanjutkan ke uji-t atau penilaian.

\section{Uji Parsial ( Uji T)}

Uji parsial digunakan untuk mengetahui pengaruh variabel $X$ terhadap variabel $\mathrm{Y}$ secara tersendiri. Pengujian yang digunakan adalah uji $t$ hitung, untuk mengetahui pengaruh variabel $\mathrm{X}$ terhadap variabel $\mathrm{Y}$ :

Jika $t_{\text {hitung }}<\mathrm{t}_{\text {tabel }}$ maka Ho diterima

Jika $t_{\text {hitung }}>t_{\text {tabel }}$ maka Ho ditolak

Dari olah data SPSS didapat $\mathrm{t}_{\text {hitung }}=$ 11.988

Untuk menghitung $t_{\text {tabel }}$ digunakan ketentuan sebagai berikut:

- $\alpha=0.05$

- $\mathrm{DF}=(\mathrm{jumlah}$ sampel -2$)$ atau 139 $-2=137$

- Ttabel $=1,665$ (hasil dari tabel t)

Karena thitung (11.988) > ttabel $(1,665)$, maka Ho ditolak artinya koefisien regresi signifikan. Berarti $t$ hitung lebih besar dari t tabel. Karena $t$ hitung lebih besar dari $\mathrm{t}$ tabel maka strategi promosi berpengaruh pada loyalitas siswa/i (konsumen). Artinya jika konsumen diberikan fasilitas strategi promosi yang baik maka dapat meningkatkan loyalitas siswa/i (konsumen) pada SMP Muhammadiyah 4 Margahayu.

\section{Analisis Regresi}

Analisis regresi yang digunakan dalam penelitiaan ini adalah regris liner sederhana. Regresi sederhana digunakan untuk mengetahui pengaruh 
variabel - variabel bebas terhadap variabel terikat. Dalam penelitian ini, regresi sederhana digunakan untuk sebagai variabel $\mathrm{X}$ terhadap loyalitas siswa/i (konsumen) sebagai variabel $\mathrm{Y}$. Analisis regresi sederhana dalam penelitian ini menggunakan SPSS Versi 16.0

\section{Hasil Analisa Regresi}

Dengan menggunakan SPSS Versi 16.0, maka diperoleh hasil analisa regresi sederhana sebagai berikut :

Tabel 6. Analisis Regresi Sederhana mengetahui pengaruh strategi promosi

(konsumen) adalah searah (positif), yang artinya bahwa peningkatan aspek strategi promosi akan mengakibatkan peningkatan terhadap loyalitas siswa (konsumen). Hal tersebut ditunjukkan pada koefisien regresi atau nilai $b$ dalam persamaan regresi tersebut yang menunjukkan angka positif sebesar 0.282. Arti persamaan regresi tersebut bahwa setiap peningkatan aspek strategi promosi sebesar 1 akan diikuti dengan peningkatan aspek loyalitas siswa (konsumen) sebesar 0.282. Demikian pula sebaliknya, jika aspek strategi promosi mengalami penurunan sebesar 1 maka aspek loyalitas siswa/i Sig(konsumen) pasti akan cenderung mengalami penurunan sebesar 0.282 . $0.09 Q_{i l a i}$ koefisien a (intercept) sebesar \begin{tabular}{c|c|c|c|c}
$\begin{array}{c}\text { Strategi } \\
\text { Promosi }\end{array}$ & 0.282 & 11.988 & 0.004 .054 yang mempunyai arti apabila \\
\hline \multicolumn{4}{c|}{ R-Square } & 0.5 idak terdapat strategi promosi $(\mathrm{X}=0)$,
\end{tabular}

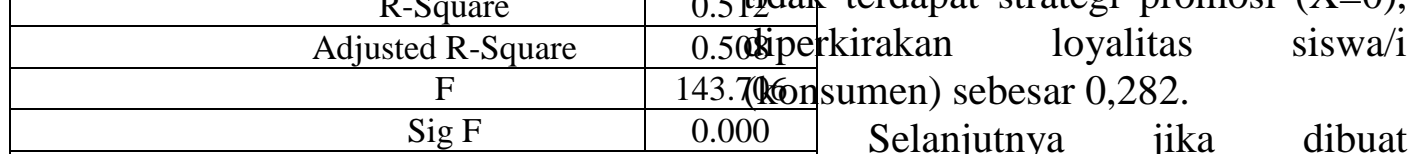
Variabel Dependen Loyalitas Siswetirsamaan garis regresi maka sumbu Y (Konsumen)

Berdasarkan hasil analisis data yang dilakukan dengan menggunakan bantuan program SPSS Versi 16.0 diperoleh bentuk persamaan regresi linear sederhana sebagai berikut:

$$
\begin{aligned}
Y & =a+b X \\
& =4.054+(0.282 \times 402.88) \\
& =4.054+113.612 \\
& =117.666
\end{aligned}
$$

Dimana :

$\mathrm{Y}=$ Loyalitas Siswa/i (Konsumen)

$\mathrm{X}=$ Strategi Promosi

Dari persamaan regresi tersebut terlihat bahwa pengaruh strategi promosi terhadap loyalitas siswa adalah 177,666 dan sumbu $X$ adalah 402,88. Koefisien regresi (b) sebesar 0,282 menunjukkan angka positif, maka terjadi kenaikan dengan asumsi tingkat strategi promosi sebesar 177,666 nilai rata - rata loyalitas konsumen tiap tahun adalah sebesar 402,88. Dari persamaan regresi diatas, dapat diartikan bahwa bila nilai strategi promosi bertambah 1 poin, maka rata rata tingkat loyalitas siswa/i (konsumen) tiap tahun akan bertambah 0,282 .

Dari perhitungan diatas, dapat digambarkan dalam persamaan garis regresi sebagai berikut : 


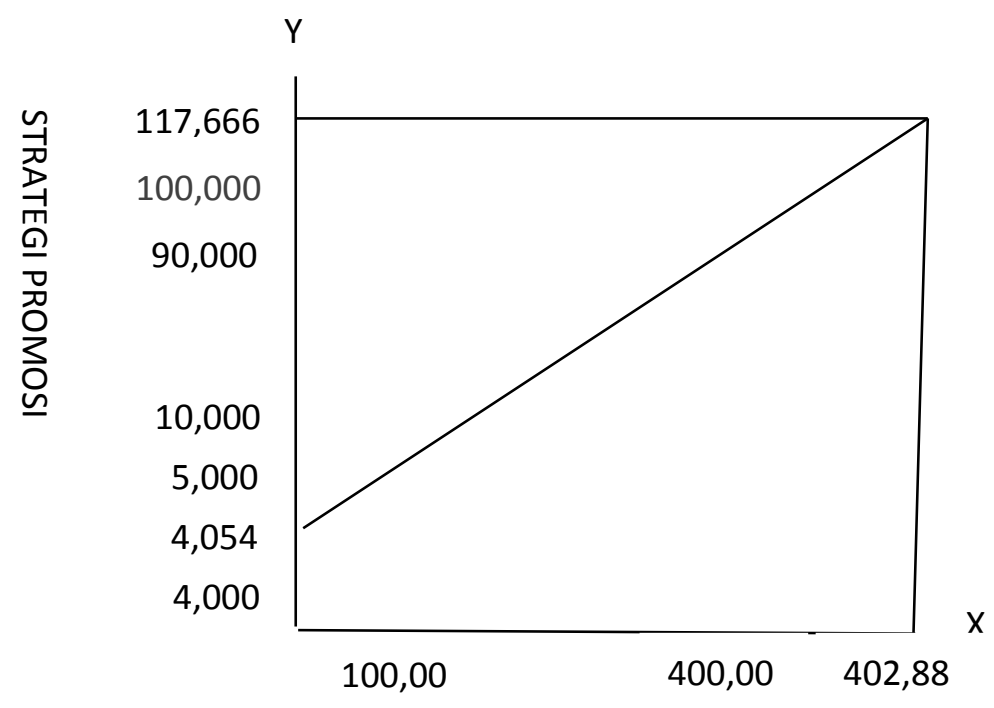

Gambar 1. Persamaan Garis Regresi LOYALITAS SISWA/i (KONSUMEN)

Berdasarkan hasil analisa diatas, dengan kenaikan 1 point nilai strategi promosi sebesar 0,282 unit / tahun, maka prediksi tingkat loyalitas siswa/i (konsumen) selama 10 tahun ke depan dapat dilihat pada gambar sebagai berikut :

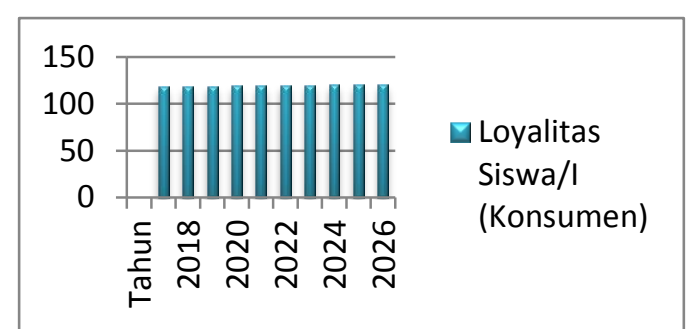

Gambar 2. Ramalan (Trend) loyalitas siswa (konsumen) 10 tahun ke depan

Gambar grafik di atas dapat disimpulkan tingkat kenaikan trend loyalitas siswa/i (konsumen) tidak terlalu terlihat. Hal tersebut disebabkan karena kenaikan setiap tahun dari perhitungan hanya 0,282 .

Tabel 7. Hasil Ramalan Loyalitas Siswa (Konsumen) 10 Tahun Ke Depan

\begin{tabular}{|c|c|}
\hline Tahun & Loyalitas Siswa/I (Konsumen) \\
\hline 2017 & 117.948 \\
\hline 2018 & 118.230 \\
\hline 2019 & 118.512 \\
\hline 2020 & 118.794 \\
\hline 2021 & 119.076 \\
\hline 2022 & 119.358 \\
\hline 2023 & 119.640 \\
\hline 2024 & 119.922 \\
\hline 2025 & 120.204 \\
\hline 2026 & 120.486 \\
\hline
\end{tabular}

Dari tabel di atas dapat disimpulkan hasil ramalan tersebut selama 10 tahun kedepan. Ramalan tersebut dapat berubah jika dilakukan 
upaya peningkatan atau perbaiki strategi promosi yang digunakan.

\section{Analisis Koefisien Determinasi ( $\mathbf{R}$} Square)

Pada tabel 4.22 di atas menunjukkan besarnya koefisien determinasi yang berfungsi untuk mengetahui besarnya persentase variabel terikat (loyalitas konsumen) yang dapat dijelaskan dengan menggunakan variabel bebas (strategi promosi). Koefisien determinasi digunakan untuk menghitung besarnya peranan atau pengaruh variabel bebas terhadap variabel terikat. Besarnya persentase variabel independen dapat menjelaskan variabel dependen dapat diketahui dari besarnya nilai koefisien determinasi yang sudah disesuaikan (Adjusted $\mathrm{R}$ Square). Hasil koefisien determinasi yang sudah disesuaikan dapat dilihat pada tabel 4.22 yang menunjukkan nilai koefisien determinasi yang sudah disesuaikan sebesar 0.508 atau sama dengan 50,8 \%. Angka tersebut berarti bahwa sebesar 50,8 \% berpengaruh cukup kuat terhadap loyalitas siswa/i (konsumen) yang terjadi dan dapat dijelaskan dengan menggunakan strategi promosi yang terdiri dari periklanan jasa pendidikan, promosi jasa pendidikan, dan humas. Sedang sisanya yaitu 49,2 \% (100\% - 50.8\%) dapat dijelaskan oleh faktor - faktor penyebab lainnsya seperti faktor dari internal maupun eksternal.

\section{SIMPULAN DAN SARAN}

Berdasarkan hasil tanggapan responden pada variabel strategi promosi dinilai baik dengan nilai rata- rata skor sebesar 3,93. Dan aspek dengan persentase tertinggi, yakni aspek periklanan jasa dan public realtion (Humas) mendapatkan persentase jawaban setuju lebih tinggi, dengan rata- rata skor sebesar 4,00 dan 3,86 yang berarti baik sementara promosi jasa pendidikan memiliki rata- rata skor sebesar 3,82 lebih rendah dari dua aspek yang lain namun tetap memiliki katagori baik. Hal tersebut menyimpulkan lembaga telah mampu menerapkan periklanan jasa pendidikan, promosi jasa pendidikan dan public relation dengan baik sehingga responden menerima media yang digunakan lembaga.

Berdasarkan hasil tanggapan responden pada variabel loyalitas siswa/I dinilai baik dengan nilai rata-rata skor sebesar 3,99. Dan dari hasil tanggapan responden seluruh aspek loyalitas siswa/i memiliki persentasi tinggi. Hal tersebut menyimpulkan lembaga telah membuat citra yang baik di benak masyarakat agar masyarakat tidak terpengaruh dengan informasi lain selain dari lembaga pendidikan tersebut.

Terdapat pengaruh strategi promosi terhadap loyalitas siswa/i pada SMP Muhammadiyah 4 Margahayu. Hal ini dibuktikan dari hasil pengukuran regresi sederhana terdapat pengaruh strategi promosi terhadap loyalitas siswa/i sebesar 50,8 persen serta nilai $t$ hitung dan signifikan yang telah dijelaskan pada bab sebelumnya. Hasil Persentase dan pengujian tersebut menyimpulkan strategi promosi yang dilakukan SMP Muhammadiyah telah dinilai cukup baik karena dapat mempengaruhi setengah lebih dari penciptaan loyalitas siswa/i. sementara sisanya sebesar 49,2 persen dipengaruhi oleh variabel lain yang tidak diteliti dalam penelitian ini, misalnya kualitas pelayanan dan variabel lainnya. 
Berdasarkan hasil penelitian yang dilakukan penulis terdapat pengaruh strategi promosi terhadap loyalitas siswa/i sebesar 50,8 persen sementara sisanya dipengaruhi faktor lain yang tidak diteliti dalam penelitian ini. Dengan demikian lembaga harus mampu mengembangkan kembali strategi promosi terutama dalam aspek promosi jasa pendidikan, lembaga dapat menggunakan media lain seperti potongan DSP jika ada anggota keluarga yang bersekolah kembali di SMP Muhammadiyah 4 Margahayu atau potongan DSP bagi pendaftar pertama pada gelombang ke satu dan ke dua. Dan mempertahankan serta mengembangkan aspek periklanan jasa pendidikan dan public relation seperti pemeliharaan web site dan akun media social lainnya serta memberikan media informasi tentang kegiatan sekolah yang di publikasikan kepada masyarakat.

Lembaga disarankan membuat skala target daya tampung siswa yang dievaluasi setiap tahun ajaran baru. Jika tidak sesuai target maka harus dicari penyebabnya dan solusi penyelesaiannya.

Setiap penelitian memiliki kekurangan dan keterbatasan dalam menganalisa suatu kasus yang terjadi di masyarakat. Penulis menyarankan, untuk penelitian di masa yang akan datang agar melakukan penelitian ini kembali karena penelitian mengenai pemasaran jasa pendidikan dirasa masih jarang, dan menganalisis faktor lain yang dapat mempengaruhi loyalitas siswa/i (konsumen) untuk melengkapi penelitian. Karena masih banyak variabel - variabel independen lain diluar penelitian ini yang mungkin dapat mempengaruhi loyalitas siswa/i (konsumen). Dan penulis berharap agar penelitian di masa yang akan datang untuk terus mengembangkan kembali penelitian dengan mengunakan metodelogi penelitian lainnya agar penelitian tersebut lebih mampu diterima oleh masyarakat.

\section{DAFTAR PUSTAKA}

Alma Buchari, Ratih. (2009).

Manajemen Corporate \&

Strategi Pemasaran Jasa

Pendidikan, Bandung: Alfabeta.

Alma Buchari. (2005). Manajemen

Pemasaran Dan Pemasaran

Jasa. Edisi Ketujuh, Bandung:

Alfabeta.

Fandy Tjiptono, (2008) Strategi

Pemasaran. Yogyakarta: PT.

Andi Offset.

Fandy Tjiptono, (2005) Brand And

Strategy Manajemen,

Yogyakarta: Andi Offset.

Kottler, Philip. (2005). Manajemen

Pemasaran Jilid 2 Edisi 11.

Jakarta: PT Tema Baru.

Kotler, Philip. Keller. (2009).

Manajemen Pemasaran Jilid 1

Edisi 13. Jakarta: Erlangga.

Kotler \& Garry Armstrong (2008).

Prinsip - Prinsip Pemasaran

(edisi terjemahan), Jakarta:

Penerbit Erlangga.

Kotler Phillip (2012). Manajemen

Pemasaran Perspektif Asia,

Buku Dua, Edisi Pertama.

Yogyakarta: Andy Offset

Kotler \& Garry Armstrong, (2004).

Prinsip - Prinsip Pemasaran,

Edisi Ketujuh. Jakarta: Penerbit

Salemba Empat.

Lee dan Johnson Carla, (2011).

Prinsip- Prinsip Periklanan

dalam Perspektif Global. Edisi

Ketiga. Jakarta: Kencana.

Nazir M, Metode Penelitia.( 2005),

Jakarta: Ghalia. 
Prasmeti, Getut. (2011). Aplikasi SPSS

Dalam Penelitian. Jakarta: Elex

Media.

Sugiyono,(2005) Metode Penelitian

Kualitatif. Bandung: Alfabeta.

Sugiyono ,(2003) Statistik Untuk

Penelitian. Bandung: Alfabeta.

Sugiyono. (2016). Metode Penelitian

Kualitatif Kuantitatif $R \& D$.

Bandung: Alfabeta,

Usman Husaini, (2011). Manajemen, teori, praktis, dan riset pendidikan. Edisi Ketiga, Bumi Aksara

Penelitian Cakra Aditia R (2011), "Pengaruh Promosi Penjualan Terhadap Loyalitas Pelanggan Strabuck Coffe". 